\title{
Protective effects of fractional extracts from Panellus serotinus on non-alcoholic fatty liver disease in obese, diabetic $d b / d b$ mice
}

\author{
Masashi Inafuku ${ }^{1}$, Koji Nagao ${ }^{1}$, Saori Nomura ${ }^{1}$, Bungo Shirouchi ${ }^{1}$, Nao Inoue ${ }^{1}$, Naoki Nagamori ${ }^{2}$, \\ Hideyuki Nakayama ${ }^{3}$, Takayoshi Toda ${ }^{4}$ and Teruyoshi Yanagita ${ }^{1 *}$ \\ ${ }^{1}$ Department of Applied Biochemistry and Food Science, Saga University, Saga 840-8502, Japan \\ ${ }^{2}$ Forestry Research Institute of Saga Prefecture, Saga 840-0212, Japan \\ ${ }^{3}$ Saga Prefectural Institute of Public Health and Pharmaceutical Research, Saga 849-0925, Japan \\ ${ }^{4}$ Department of Clinical Laboratory Medicine, University of the Ryukyus Hospital, Okinawa 903-0125, Japan
}

(Received 2 February 2011 - Revised 7 April 2011 - Accepted 12 May 2011 - First published online 26 July 2011)

\section{Abstract}

Non-alcoholic fatty liver disease (NAFLD) is emerging as the most common liver disease in industrialised countries. Various mushrooms have been used in Eastern folk medicine for the treatment of lifestyle diseases. We previously found that the dietary intake of powdered whole Panellus serotinus (Mukitake) alleviates NAFLD in obese, diabetic $d b / d b$ mice. In the present study, we investigated the influence of Mukitake fractional extracts on the development of NAFLD in $d b / d b$ mice. A significant reduction in the hepatic TAG content, macrovesicular hepatocytes and activities of key enzymes for de novo synthesis of the fatty acid was observed in both the water-soluble Mukitake extract (WE) diet and the ethanol-soluble Mukitake extract (EE) diet groups compared with the control diet group of the $d b / d b$ mice. The serum level of monocyte chemoattractant protein-1 (MCP-1), which is known to exacerbate insulin resistance, was significantly decreased in the WE group. On the other hand, the serum level of adiponectin, which plays a protective role against the metabolic syndrome, was significantly increased in the EE group. Additionally, differential analysis between Mukitake and Shiitake, mycelia from the same family, using liquid chromatography time-of-flight MS technology revealed that only seven and five compounds exist in WE and EE from Mukitake, respectively. In conclusion, the present study demonstrated that Mukitake displays at least two different physiological actions that alleviate NAFLD: one through the reduction in inflammatory damage by its suppression in MCP-1 production and the other through an increase in level of serum adiponectin and the prevention of visceral fat accumulation.

Key words: Adiponectin: $d b / d b$ Mouse: Monocyte chemoattractant protein-1: Non-alcoholic fatty liver disease: Panellus serotinus

The metabolic syndrome, which comprises a cluster of metabolic abnormalities such as hyperlipidaemia, diabetes mellitus and hypertension, is a widespread and increasingly prevalent disease in industrialised countries and contributes to an increase in cardiovascular morbidity and mortality ${ }^{(1,2)}$. Non-alcoholic fatty liver disease (NAFLD) is now recognised as the hepatic manifestation of the metabolic syndrome and is emerging as one of the most common causes of chronic liver disease worldwide ${ }^{(3-6)}$. NAFLD encompasses a wide disease spectrum ranging from simple hepatic steatosis to steatohepatitis, advanced fibrosis and cirrhosis ${ }^{(7-9)}$. Liverrelated morbidity and mortality due to NAFLD are observed in patients who have advanced fibrosis and cirrhosis ${ }^{(10)}$. Although the mechanisms that accelerate the progression of simple steatosis towards more debilitating and advanced stages of NAFLD remain poorly understood, a 'two-hit' hypothesis has been put forward ${ }^{(11)}$. Hepatic fat accumulation, which was initially thought to be relatively benign, represents the 'first hit'. Studies have suggested that fat accumulation in hepatocytes is the hallmark of NAFLD and leaves them highly vulnerable to a 'second hit', for example, injury by oxidative stress and inflammatory cytokines, such as TNF- $\alpha$ and monocyte chemoattractant protein-1 (MCP-1).

At present, no pharmacotherapy is available that can fully reverse or prevent steatohepatitis ${ }^{(12)}$. We have recognised that diet and its components contribute to the development and prevention of NAFLD ${ }^{(13-15)}$. Therefore, it is necessary to develop effective therapies for the treatment of the early stages of NAFLD and the discovery of nutrients that reduce the risk of NAFLD would be useful. In Eastern traditional

Abbreviations: CO, control; EE, ethanol-soluble Mukitake extract; FAS, fatty acid synthase; IKK $\beta$, inhibitor of $\kappa \mathrm{B}$ kinase- $\beta$; IRS, insulin receptor substrate; MCP-1, monocyte chemoattractant protein-1; NAFLD, non-alcoholic fatty liver disease; WAT, white adipose tissues; WE, water-soluble Mukitake extract. 
therapy, many species of edible mushrooms, such as Lentinus edodes (Shiitake) and Lyophyllum decastes (Hatakeshimeji), have been used for the treatment of various diseases, including lifestyle diseases ${ }^{(16-21)}$. Panellus serotinus (Mukitake), which belongs to same family of mycelia such as Shiitake and Hatakeshimeji, is recognised as one of the most delicious edible mushrooms. Technology for the artificial cultivation of Mukitake in plastic greenhouses has recently been developed $^{(22)}$ and has contributed to the constant availability of this mushroom in the market. We previously ${ }^{(23)}$ found that the dietary intake of powdered whole Mukitake alleviates NAFLD in $d b / d b$ mice, an animal model for obesity. In the present study, we investigated the influence of Mukitake fractional extracts on the development of NAFLD in $d b / d b$ mice in order to determine the physiologically active substances in Mukitake and to understand the mechanisms by which they work.

\section{Animals and experimental diets}

All animal procedures were performed in accordance with the guidelines provided by the ethics committee on experimental animal care at Saga University, Saga, Japan. A total of six C57BL/6J mice and eighteen BKS.Cg- + Leprdb/+Leprdb/Jc1 $(d b / d b)$ mice (5 weeks old, male) were purchased from CLEA Japan, Inc. (Tokyo, Japan). The mice were housed individually in plastic cages, kept at $24^{\circ} \mathrm{C}$ on a $12 \mathrm{~h} \mathrm{light}-12 \mathrm{~h}$ dark cycle. After a week-long adaptation period, the $d b / d b$ mice were randomly divided into three groups: a control (CO) diet group; a WE diet group; an EE diet group. The basal semi-synthetic diets were prepared according to the AIN-76 formulation. The WE and EE groups were fed $3 \%$ of their respective Mukitake soluble extracts, which were substituted for sucrose in the basal diet (Table 1). The C57BL/6J mice, the progenitors of $d b / d b$ mice, were fed the CO diet as the normal group. The mice consumed the diets using Rodent CAFÉ (KBT Oriental Company Limited, Saga, Japan) and were given ad libitum water for 4 weeks. At the end of the feeding period, the mice were killed by exsanguination from the heart under anaesthesia with pentobarbital sodium salt after a $9 \mathrm{~h}$ starvation. White adipose tissues (WAT) and liver were excised, and the serum was separated from the
Table 1. Composition of the experimental diets $(\mathrm{g} / 100 \mathrm{~g})$

\begin{tabular}{|c|c|c|c|}
\hline \multirow[b]{2}{*}{ Ingredient } & \multicolumn{3}{|c|}{ Diet } \\
\hline & Control & WE & EE \\
\hline Casein & $20 \cdot 0$ & $20 \cdot 0$ & $20 \cdot 0$ \\
\hline$\beta$-Maize starch & $15 \cdot 0$ & $15 \cdot 0$ & $15 \cdot 0$ \\
\hline Cellulose & $5 \cdot 0$ & $5 \cdot 0$ & $5 \cdot 0$ \\
\hline Mineral mixture (AIN-76) & 3.5 & 3.5 & 3.5 \\
\hline Vitamin mixture (AIN-76) & 1.0 & $1 \cdot 0$ & 1.0 \\
\hline DL-Met & 0.3 & 0.3 & 0.3 \\
\hline Choline bitartrate & 0.2 & 0.2 & 0.2 \\
\hline Maize oil & $5 \cdot 0$ & $5 \cdot 0$ & 5.0 \\
\hline WE & - & 3.0 & - \\
\hline EE & - & - & 3.0 \\
\hline Sucrose & & to make 10 & \\
\hline
\end{tabular}

WE, water-soluble Mukitake extract; EE, ethanol-soluble Mukitake extract.

blood. The tissues and serum were immediately frozen in liquid $\mathrm{N}_{2}$, and were stored at $-80^{\circ} \mathrm{C}$ until analyses.

\section{Measurement of serum parameters}

TAG and cholesterol levels, as well as alanine aminotransferase activity, in the serum were measured using commercially available enzymatic kits (Wako Pure Chemical Industries, Limited, Osaka, Japan). The levels of MCP-1, total adiponectin and insulin in the serum were measured using commercial ELISA kits purchased from R\&D Systems, Inc. (Minneapolis, MN, USA), Otsuka Company, Limited (Tokyo, Japan) and Shibayagi Company, Limited (Gunma, Japan), respectively.

\section{Assay of lipid levels and lipogenic enzyme activity in the liver}

Liver lipids were extracted and purified according to a method reported previously ${ }^{(24)}$. TAG and total cholesterol levels were determined by the methods of Fletcher ${ }^{(25)}$ and Sperry \& $\mathrm{Webb}^{(26)}$, respectively. The activities of malic enzyme, glucose-6-phosphate dehydrogenase and fatty acid synthase (FAS) in the hepatic cytosolic fraction were determined as described elsewhere ${ }^{(27-29)}$.

\section{Histopathological study of the liver}

The livers were excised and immediately fixed in 10\% buffered formalin for histological examinations. Formalin-fixed liver tissue samples were embedded in paraffin and sectioned into $4 \mu \mathrm{m}$ thicknesses. The liver tissue sections were stained by haematoxylin-eosin to microscopically evaluate the degree of NAFLD.

\section{Analysis of mRNA expression}

Total RNA was extracted from $100 \mathrm{mg}$ of perirenal WAT and liver using an RNeasy Midi Kit and an RNeasy Lipid Tissue Mini Kit from Qiagen Science (Germantown, MD, USA). A TaqMan Universal PCR Master Mix from Applied Biosystems (Bedford, CA, USA), and Assay-on-Demand, Gene Expression Products (Mm00443258_m1 for TNF- $\alpha$, 
Mm00441242_m1 for MCP-1, Mm00440939_m1 for PPAR $\alpha$, Mm00440945_m1 for PPAR $\gamma$, Mm00439693_m1 for insulin receptor, Mm00439720_m1 for insulin receptor substrate (IRS) 1, Mm03038438_m1 for IRS2 and Hs99999901_s1 for 18S RNA as an internal control for normalisation), purchased from Applied Biosystems, were used to measure the mRNA expression level of each gene in the quantitative real-time RT-PCR analysis. The amplifications were performed with a commercial real-time PCR system (ABI Prism 7000 Sequence Detection System; Applied Biosystems).

\section{Liquid chromatography time-of-flight MS analysis}

Whole Mukitake powder, WE, EE and whole Shiitake powder were suspended in $20 \% \mathrm{MeCN}$. All the samples were analysed on a 1100 Series HPLC system, coupled with a G1969A TOF mass spectrometer system (Agilent Technologies, Santa Clara, CA, USA), operating in the positive-ion mode. A chromatographic separation was achieved on a $2 \cdot 1 \times 100 \mathrm{~mm}$, 드 $3.5 \mu \mathrm{m}$ particle size Zorbax Eclipse plus C18 column (Agilent Technologies). Liquid chromatography parameters were as follows: solvent A was $15 \% \mathrm{MeCN}+0 \cdot 1 \%$ formic

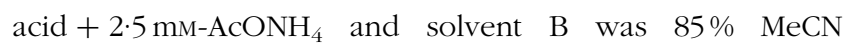

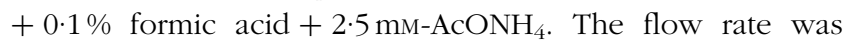
$0.2 \mathrm{ml} / \mathrm{min}$, and the solvent gradient program was $15 \% \mathrm{~B}$ at time $0,100 \% \mathrm{~B}$ at time $15 \mathrm{~min}$ and $100 \% \mathrm{~B}$ at $30 \mathrm{~min}$. The injection volume was $5 \mu \mathrm{l}$ and the column temperature was set at $40^{\circ} \mathrm{C}$. Electrospray ionization capillary voltage was set at $4000 \mathrm{~V}$ and the fragmentor at $120 \mathrm{~V}$. The liquid nebuliser was set to $50 \mathrm{psig}(345 \mathrm{kPa})$ and the nitrogen-drying gas was set to a flow rate of 10 litres $/ \mathrm{min}$. The drying gas temperature was maintained at $350^{\circ} \mathrm{C}$. The stored mass range was $\mathrm{m} / \mathrm{z}$ 80-1200. MassHunter Workstation Data acquisition software (Agilent Technologies) was used to operate the instrumentation. The data were processed using MassHunter Qualitative Analysis software (Agilent Technologies). The compounds were extracted from the raw data using the Molecular Feature Extraction algorithm in the MassHunter Qualitative Analysis software.

\section{Statistical analysis}

All values are expressed as means with their standard errors. The significant difference of means between $\mathrm{C} 57 \mathrm{BL} / 6 \mathrm{~J}$ and $d b / d b$ mice fed the CO diet was determined by Student's $t$ test. For significance of the difference between means for the three groups of $d b / d b$ mice, data were analysed by one-way ANOVA, and then the differences among the mean values were inspected using the Tukey-Kramer multiple comparison tests. Differences were considered significant at $P<0 \cdot 05$. Pearson's correlation coefficient test was used to assess the correlations between the variables.

\section{Results}

After experimental feeding, the dietary intake of the CO diet contributed to significant increases in body weight gain and in the weights of each WAT in $d b / d b$ mice compared with those in C57BL/6J mice (Table 2). Although no significant difference was shown in dietary intake between the groups of $d b / d b$ mice, body weight gain and omental WAT weight were significantly lower in the $\mathrm{EE}$ group than in the $\mathrm{CO}$ group. Hepatomegaly, macrovesicular steatosis and hepatic TAG accumulation were observed in $d b / d b$ mice fed the CO diet (Fig. 1). However, hepatic TAG accumulation and macrovesicular steatosis were markedly alleviated in both the WE and the EE groups compared with the CO group. Moderate hyperlipidaemia was observed in $d b / d b$ mice compared with C57BL/6J mice, and the three groups of $d b / d b$ mice did not differ in their levels of serum lipid parameters (Table 3). As shown in Table 3, severe hyperinsulinaemia was also observed in control-fed $d b / d b$ mice and tended to be alleviated (by 39\%) in the WE group of $d b / d b$ mice. Consistent with the development of hepatic steatosis, the hepatic injury marker (alanine aminotransferase activity) in the serum was significantly increased in $d b / d b$ mice fed the CO diet in comparison with the $\mathrm{C} 57 \mathrm{BL} / 6 \mathrm{~J}$ mice (Fig. 2). The injury marker was significantly decreased by dietary intake of Mukitake water extract in $d b / d b$ mice. The serum level of MCP-1 was

Table 2. Effects of Mukitake extracts on growth parameters (Mean values with their standard errors, $n 6$ )

\begin{tabular}{|c|c|c|c|c|c|c|c|c|}
\hline \multirow[b]{3}{*}{ Parameters } & \multirow{2}{*}{\multicolumn{2}{|c|}{$\frac{\text { C57BL/6J mice }}{\text { NO group }}$}} & \multicolumn{6}{|c|}{$d b / d b$ mice } \\
\hline & & & \multicolumn{2}{|c|}{ CO group } & \multicolumn{2}{|c|}{ WE group } & \multicolumn{2}{|c|}{ EE group } \\
\hline & Mean & SEM & Mean & SEM & Mean & SEM & Mean & SEM \\
\hline Food intake (g/4 weeks) & $80 \cdot 6$ & $4 \cdot 0$ & $161^{*}$ & 4 & 162 & 1 & 162 & 2 \\
\hline Body weight gain $(\mathrm{g})$ & 3.83 & 0.45 & $6 \cdot 28^{\star a}$ & 0.71 & $1 \cdot 38^{\mathrm{b}}$ & 0.76 & $3.50^{\mathrm{b}}$ & 0.44 \\
\hline Liver ( $\mathrm{g} / 100 \mathrm{~g}$ body weight) & 3.98 & 0.05 & $5 \cdot 52^{*}$ & 0.18 & 5.07 & 0.20 & $5 \cdot 64$ & 0.09 \\
\hline \multicolumn{9}{|c|}{ White adipose tissue ( $\mathrm{g} / 100 \mathrm{~g}$ body weight) } \\
\hline Total & $6 \cdot 80$ & 0.33 & $22 \cdot 5^{\star}$ & 0.2 & $21 \cdot 3$ & 0.6 & $21 \cdot 4$ & 0.5 \\
\hline Perirenal & 0.899 & 0.078 & $2 \cdot 82^{*}$ & 0.09 & $2 \cdot 73$ & 0.10 & 2.68 & $0 \cdot 10$ \\
\hline Epididymal & $2 \cdot 13$ & 0.07 & $4.68^{\star}$ & 0.14 & 4.80 & 0.10 & 4.73 & 0.14 \\
\hline Omental & $1 \cdot 24$ & 0.07 & $3.36^{\star a}$ & 0.09 & $3 \cdot 13^{a, b}$ & 0.07 & $2.95^{\mathrm{b}}$ & 0.08 \\
\hline Subcutaneous & 2.53 & 0.18 & $11 \cdot 7^{*}$ & 0.2 & $10 \cdot 6$ & 0.5 & $11 \cdot 1$ & 0.4 \\
\hline
\end{tabular}

NO, normal; CO, control; WE, water-soluble Mukitake extract; EE, ethanol-soluble Mukitake extract.

${ }^{\mathrm{a}, \mathrm{b}}$ Mean values with unlike superscript letters were significantly different between each experimental diet group of $d b / d b$ mice $(P<0.05)$.

${ }^{*}$ Mean values were significantly different between the NO and CO groups $(P<0.05)$. 
(a)

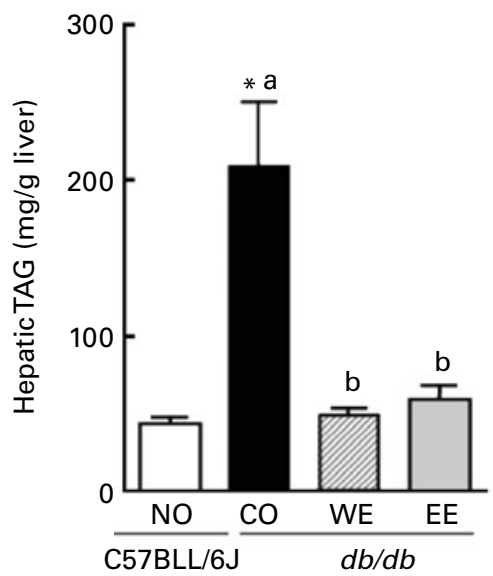

(b)

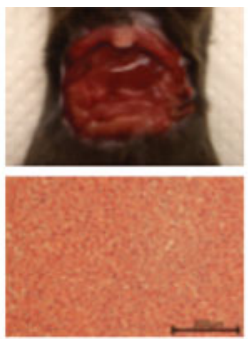

NO group
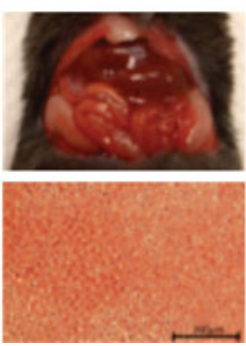

WE group

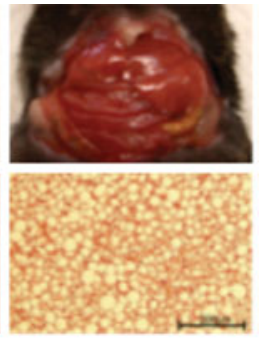

CO group

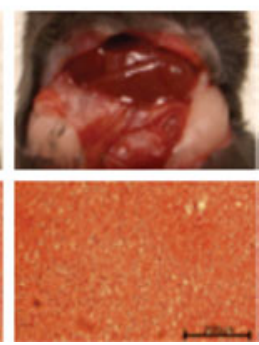

EE group

Fig. 1. (a) Liver histology and TAG levels in C57BL/6J and $d b / d b$ mice. Mice were fed the experimental diets for 4 weeks. See Table 1 for compositions of diets. (b) Haematoxylin and eosin staining of liver sections from representative mice of each experimental group (scale bar $=200 \mu m$ ). Values are means, with their standard errors represented by vertical bars, $n 6$. * Mean values were significantly different between the normal $(\mathrm{NO})$ and control $(\mathrm{CO})$ groups $(P<0 \cdot 05)$. a,b Mean values with unlike letters were significantly different between each experimental diet group of $d b / d b$ mice $(P<0.05)$. WE, water-soluble Mukitake extract; $\mathrm{EE}$, ethanol-soluble Mukitake extract.

drastically increased in the control-fed $d b / d b$ mice compared with the $\mathrm{C} 57 \mathrm{BL} / 6 \mathrm{~J}$ mice, and it was significantly decreased in the WE group compared with the CO group of $d b / d b$ mice (Fig. 2). A highly positive correlation was found between the serum MCP-1 level and the hepatic injury marker in $d b / d b$ mice $(r 0.6943, P=0.002, n$ 18). On the other hand, the serum level of adiponectin was markedly decreased in the control-fed $d b / d b$ mice compared with the C57BL/6J mice, and it was significantly increased in the EE group compared with the CO group of $d b / d b$ mice (Table 3 ).

To examine further the effects of the Mukitake extract on the liver, the activities of key lipogenic enzymes (malic enzyme, glucose-6-phosphate dehydrogenase and FAS) were analysed (Table 4). The activities of malic enzyme and glucose-6-phosphate dehydrogenase, which supply nicotinamide adenine dinucleotide phosphate required for FAS activity, were significantly decreased in the WE group compared with the CO group of $d b / d b$ mice. The WE group also showed a significant decrease in the activity of FAS, a key enzyme for the de novo synthesis of fatty acid. In the EE group, the activities of glucose-6-phosphate dehydrogenase and FAS were significantly lower than in the CO group.

To gain an insight into the effect of Mukitake fractional extracts on the levels of mRNA related to insulin signalling, we examined the mRNA expression of genes in perirenal WAT and liver by real-time RT-PCR (Table 5). Compared with the $\mathrm{C} 57 \mathrm{BL} / 6 \mathrm{~J}$ mice, mRNA expression of MCP-1 and TNF- $\alpha$, which is known to exacerbate insulin resistance, was markedly increased, and that of PPAR, which are known to increase insulin sensitivity, was significantly decreased in the WAT of $d b / d b$ mice fed the CO diet. The alterations in mRNA expression of MCP-1 and PPAR were alleviated by the

Table 3. Effects of Mukitake extracts on serum parameters

(Mean values with their standard errors, $n 6$ )

\begin{tabular}{|c|c|c|c|c|c|c|c|c|}
\hline Parameters† & \multicolumn{2}{|c|}{$\begin{array}{c}\text { C57BL/6J mice } \\
\text { NO group }\end{array}$} & \multicolumn{2}{|c|}{ CO group } & \multicolumn{2}{|c|}{ WE group } & \multicolumn{2}{|c|}{ EE group } \\
\hline TAG (mg/l) & $199 \cdot 0$ & $26 \cdot 0$ & $225 \cdot 0$ & $40 \cdot 0$ & $328 \cdot 0$ & $51 \cdot 0$ & $353 \cdot 0$ & $87 \cdot 0$ \\
\hline Cholesterol (mg/l) & $909 \cdot 0$ & $27 \cdot 0$ & $1330 \cdot 0^{\star}$ & $30 \cdot 0$ & $1460 \cdot 0$ & $80 \cdot 0$ & $1490 \cdot 0$ & $90 \cdot 0$ \\
\hline Insulin (ng/ml) & $2 \cdot 24$ & 0.43 & $31 \cdot 8^{*}$ & $6 \cdot 4$ & $19 \cdot 5$ & $3 \cdot 4$ & $29 \cdot 2$ & $5 \cdot 7$ \\
\hline Adiponectin $(\mu \mathrm{g} / \mathrm{ml})$ & $22 \cdot 6$ & 0.4 & $12 \cdot 3^{\star a}$ & 0.5 & $14 \cdot 1^{\mathrm{a}, \mathrm{b}}$ & 0.8 & $15 \cdot 8^{\mathrm{b}}$ & 1.0 \\
\hline
\end{tabular}

NO, normal; CO, control; WE, water-soluble Mukitake extract; EE, ethanol-soluble Mukitake extract.

${ }_{\mathrm{a}, \mathrm{b}}$ Mean values with unlike superscript letters were significantly different between each experimental diet group of $d b / d b$ mice $(P<0.05)$.

* Mean values were significantly different between the NO and CO groups $(P<0.05)$.

$\dagger$ Parameters used: alanine aminotransferase and monocyte chemoattractant protein-1. 
(a)

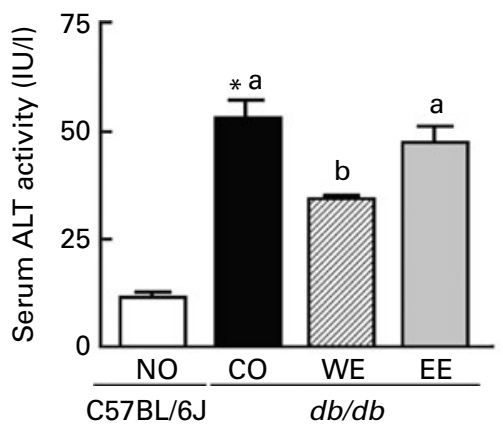

(b)

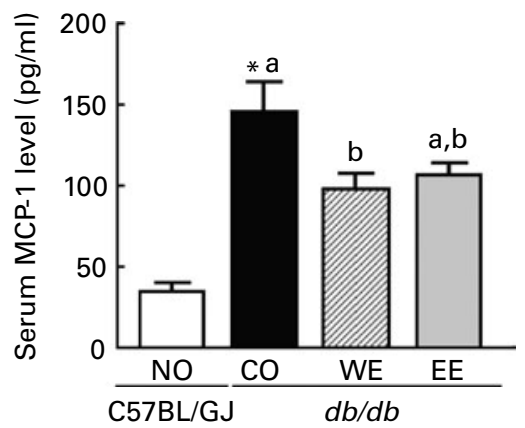

Fig. 2. (a) Hepatic injury marker activities and (b) monocyte chemoattractant protein-1 (MCP-1) levels in the sera of C57BL/6J and $d b / d b$ mice. Mice were fed the experimental diets for 4 weeks. See Table 1 for compositions of diets. Values are means, with their standard errors represented by vertical bars, $n 6$. * Mean values were significantly different between the normal (NO) and control (CO) groups $(P<0.05)$. ${ }^{a, b}$ Mean values with unlike letters were significantly different between each experimental diet group of $d b / d b$ mice $(P<0.05)$. WE, water-soluble Mukitake extract; EE, ethanol-soluble Mukitake extract; ALT, alanine aminotransferase.

dietary intake of WE in $d b / d b$ mice. The EE group showed a decrease in TNF- $\alpha$ mRNA expression in WAT. In the liver, the mRNA expression level of IRS1, which plays a pivotal role in insulin signal transduction, was significantly lower in $d b / d b$ mice fed the CO diet than in the C57BL/6J mice. The significant decrease in IRS1 mRNA expression was ameliorated in the WE group of $d b / d b$ mice. mRNA expression levels of MCP-1 and TNF- $\alpha$ were lower in the WE group than in the CO group of $d b / d b$ mice.

Liquid chromatography time-of-flight MS profiles revealed that a total of 184 ions were detected in whole Mukitake powder (data not shown); 151 of these ions matched the ions detected in whole Shiitake powder (data not shown) and the other thirty-three of these ions were featured as ions peculiar to Mukitake (Fig. 3 and Table 6). Additionally, fifteen of thirty-three Mukitake featured ions were detected in Mukitake fractional extracts; seven, five and three of these ions matched for ions detected in WE, EE and both extracts, respectively (Fig. 3 and Table 6).

\section{Discussion}

We investigated the effects of Mukitake fractional extracts on the development of NAFLD in $d b / d b$ mice. The results suggested that dietary intake of WE prevents the development of NAFLD partly through the suppression of hepatic lipogenesis and the reduction of MCP-1 production in $d b / d b$ mice. Additionally, the results also suggested that hepatic steatosis was prevented by the suppression of fatty acid synthesis in the liver and the enhancement of serum adiponectin levels in EE-fed $d b / d b$ mice.

The $d b / d b$ mice have a functional defect in the leptin receptor, which causes them to suffer from hyperphagia and develop a syndrome involving multiple metabolic and hormonal disorders, which shares many features with the human metabolic syndrome ${ }^{(30-32)}$. In the present study, hepatic TAG mass measurement and histopathological evidence clearly show that NAFLD developed in $d b / d b$ mice fed a CO diet (Fig. 1). A significant reduction in hepatic TAG content, macrovesicular hepatocytes and activities of key enzymes for de novo synthesis of fatty acids was observed in both the WE and EE groups of $d b / d b$ mice. Therefore, it was suggested that dietary intakes of both Mukitake fractional extracts can alleviate hepatic fat accumulation, a 'first hit' in the 'two-hit' hypothesis described above.

Various studies ${ }^{(33-35)}$ have indicated that insulin resistance is the essential first pathological step in the development of NAFLD. In fact, hepatic steatosis is now proposed to be a feature of the insulin resistance syndrome along with type 2 diabetes, visceral obesity and hyperlipidaemia ${ }^{(33-35)}$. After the experimental feeding period, $d b / d b$ mice fed the CO diet had severe hyperinsulinaemia as one feature of type 2

Table 4. Activities of hepatic enzymes in the cytosolic fraction (nmol/min per mg protein)

(Mean values with their standard errors, $n 6$ )

\begin{tabular}{|c|c|c|c|c|c|c|c|c|}
\hline \multirow[b]{3}{*}{ Enzyme } & \multirow{2}{*}{\multicolumn{2}{|c|}{$\frac{\text { C57BL/6J mice }}{\text { NO group }}$}} & \multicolumn{6}{|c|}{$d b / d b$ mice } \\
\hline & & & \multicolumn{2}{|c|}{$\mathrm{CO}$ group } & \multicolumn{2}{|c|}{ WE group } & \multicolumn{2}{|c|}{ EE group } \\
\hline & Mean & SEM & Mean & SEM & Mean & SEM & Mean & SEM \\
\hline ME & $88 \cdot 8$ & $4 \cdot 7$ & $70 \cdot 1^{a}$ & 8.4 & $31 \cdot 5^{\mathrm{b}}$ & $5 \cdot 6$ & $48 \cdot 3^{a, b}$ & $6 \cdot 2$ \\
\hline G6PDH & $7 \cdot 63$ & $1 \cdot 13$ & $3 \cdot 19^{\star a}$ & 0.24 & $1.99^{b}$ & 0.08 & $2 \cdot 07^{b}$ & 0.06 \\
\hline FAS & $9 \cdot 39$ & 0.49 & $7 \cdot 00^{\mathrm{a}}$ & 1.08 & $2 \cdot 47^{b}$ & 0.56 & $3.82^{b}$ & 0.58 \\
\hline
\end{tabular}

NO, normal; CO, control; WE, water-soluble Mukitake extract; $\mathrm{EE}$, ethanol-soluble Mukitake extract; ME, malic enzyme; G6PDH, glucose-6-phosphate dehydrogenase; FAS, fatty acid synthase.

${ }^{\mathrm{a}, \mathrm{b}}$ Mean values with unlike superscript letters were significantly different between each experimental diet group of $d b / d b$ mice $(P<0.05)$.

${ }^{*}$ Mean values were significantly different between the NO and CO groups $(P<0.05)$. 
Table 5. Effect of experimental diets on mRNA expression of genes related to insulin signaling in the liver and perirenal white adipose tissue (arbitrary units)

(Mean values with their standard errors, $n 6$ )

\begin{tabular}{|c|c|c|c|c|c|c|c|c|}
\hline \multirow[b]{3}{*}{ Enzyme } & \multirow{2}{*}{\multicolumn{2}{|c|}{$\frac{\text { C57BL/6J mice }}{\text { NO group }}$}} & \multicolumn{6}{|c|}{$d b / d b$ mice } \\
\hline & & & \multicolumn{2}{|c|}{$\mathrm{CO}$ group } & \multicolumn{2}{|c|}{ WE group } & \multicolumn{2}{|c|}{ EE group } \\
\hline & Mean & SEM & Mean & SEM & Mean & SEM & Mean & SEM \\
\hline \multicolumn{9}{|c|}{ Perirenal WAT } \\
\hline MCP-1 & 0.06 & 0.00 & $1.00^{\mathrm{a}}$ & 0.21 & $0.33^{b}$ & 0.07 & $0.39^{b}$ & 0.07 \\
\hline TNF- $\alpha$ & 0.14 & 0.10 & 1.00 & 0.32 & 0.78 & 0.30 & 0.39 & 0.05 \\
\hline $\operatorname{PPAR} \alpha$ & 3.43 & 0.61 & $1.00^{*}$ & 0.25 & $2 \cdot 29$ & 0.89 & 0.82 & 0.10 \\
\hline \multicolumn{9}{|l|}{ Liver } \\
\hline MCP-1 & 0.43 & 0.09 & 1.00 & 0.48 & 0.26 & 0.09 & 0.48 & 0.14 \\
\hline TNF- $\alpha$ & 0.80 & 0.25 & 1.00 & 0.62 & 0.15 & 0.03 & 0.80 & 0.33 \\
\hline InsR & 0.84 & 0.11 & 1.00 & 0.14 & 0.77 & 0.06 & 0.76 & 0.15 \\
\hline IRS1 & 1.66 & 0.17 & $1.00^{\star a}$ & $0 \cdot 11$ & $1.95^{\mathrm{b}}$ & 0.17 & $1.51^{a, b}$ & 0.15 \\
\hline IRS2 & 1.95 & 0.12 & 1.00 & 0.15 & 0.96 & 0.11 & 0.96 & 0.09 \\
\hline
\end{tabular}

NO, normal; CO, control; WE, water-soluble Mukitake extract; EE, ethanol-soluble Mukitake extract; WAT, white adipose tissue; MCP-1, monocyte chemoattractant protein 1; InsR, insulin receptor; IRS, insulin receptor substrate.

${ }^{a, b}$ Mean values with unlike superscript letters were significantly different between each experimental diet group of $d b / d b$ mice $(P<0.05)$.

${ }^{*}$ Mean values were significantly different between the NO and $\mathrm{CO}$ groups $(P<0.05)$.

diabetes (Table 3). Dietary intake of WE tended to decrease the serum insulin level (by $40 \%$ ) and the hepatic TNF- $\alpha$ mRNA expression (by 85\%), whereas IRS1 mRNA expression in the liver was significantly increased in the WE group (Tables 3 and 5). Given the fact that TNF- $\alpha$ impairs insulin signalling through the inhibition of the IRS1 function ${ }^{(36)}$, improvement in insulin sensitivity by the intake of WE contributed to the prevention of hepatic steatosis in $d b / d b$ mice. Dietary intake of WE also prevented the elevation of serum alanine aminotransferase activity (Fig. 2), which is the most common presentation of NAFLD at any stage ${ }^{(37)}$. Adipose tissue not only stores excess energy in the form of fat but also secretes physiologically active substances called adipocytokines, such as TNF- $\alpha$ and MCP-1. MCP-1 is a member of the CC chemokine family and induces inflammatory responses through the recruitment of inflammatory cells. It is up-regulated by inflammatory stimuli such as TNF- $\alpha^{(38,39)}$. Recent findings ${ }^{(40)}$ have also shown that MCP-1 is a key molecule in insulin resistance and NAFLD as a 'second hit' in the 'two-hit' hypothesis. In the present study, serum MCP-1 levels and MCP-1 mRNA expression in the liver and WAT were markedly increased in control-fed $d b / d b$ mice compared with $\mathrm{C} 57 \mathrm{BL} / 6 \mathrm{~J}$ mice, and the drastic increases in $d b / d b$ mice were ameliorated by dietary intake of WE (Fig. 2 and Table 5). The highly positive correlation between serum MCP-1 level and the hepatic injury marker was observed in both the present study and a previous study $^{(23)}$. MCP-1 mRNA expression has been known to be regulated by the activation of transcription factor $\mathrm{NF}-\kappa \mathrm{B}$, and the phosphorylation of the inhibitor of $\kappa \mathrm{B}$ kinase- $\beta$ (IKK $\beta$ ) triggers the activation of NF- $\mathrm{KB}$ in response to pro-inflammatory stimuli ${ }^{(41-43)}$. Our previous study ${ }^{(23)}$ indicated that the dietary intake of whole Mukitake powder prevents the development of NAFLD through the suppression of MCP-1 production in $d b / d b$ mice, and that WE inhibits IKK $\beta$ activity in vitro. Given the fact that an inhibitor of IKK $\beta$ prevented insulin resistance in diabetic mice ${ }^{(44)}$, the results led us to speculate that WE prevented the development and progression of
NAFLD by the reduction in MCP-1 production through interference in the IKK $\beta-\mathrm{NF}-\kappa \mathrm{B}$ signalling pathway in $d b / d b$ mice.

On the other hand, a significant reduction in omental (visceral) fat weight and a significant increase in serum adiponectin levels were observed in $d b / d b$ mice fed EE (Tables 2 and 3). Visceral fat is more strongly related to metabolic risk factors than any other fat compartment ${ }^{(45)}$ and adiponectin, one of the most abundant adipocytokines, has been strongly suggested to play a protective role against the metabolic syndrome ${ }^{(46-49)}$. Although the apparent amelioration of hyperinsulinaemia and hepatic injury was not observed in

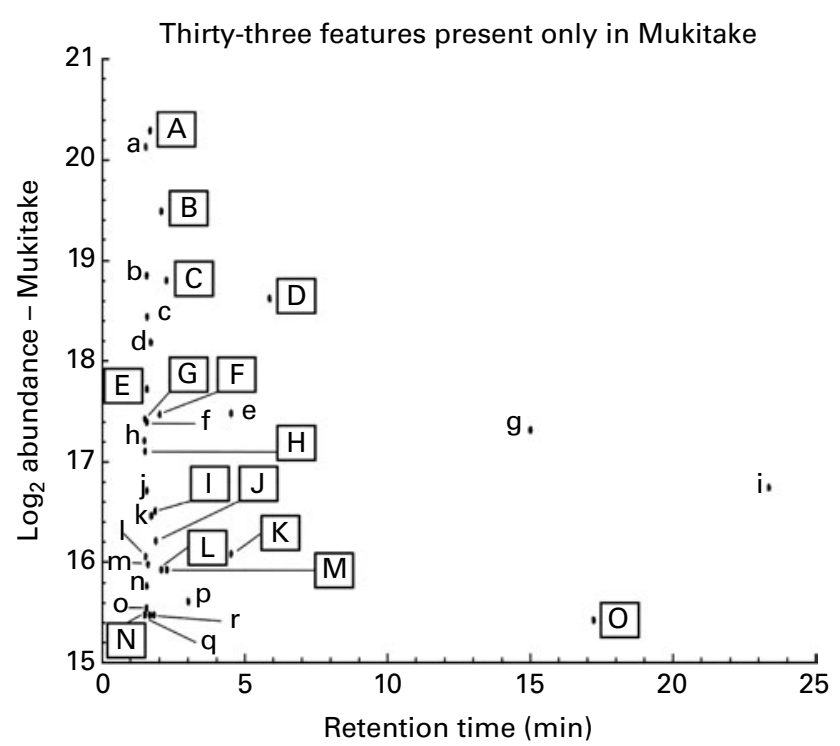

Fig. 3. Differential analysis between Mukitake and Shiitake using liquid chromatography time-of-flight MS. Whole Mukitake powder, water-soluble Mukitake extract, ethanol-soluble Mukitake extract and whole Shitake powder were analysed on a 1100 Series HPLC system coupled with a G1969A TOF mass spectrometer system. See Table 6 for presumptive formula of thirty-three Mukitake featured ions. A, E, H, K, L: detected in ethanolsoluble extract; C, D, F, J, M, N, O: detected in water-soluble extract; B, G, I: detected in both extracts. 
Table 6. Presumptive formula of Mukitake featured ions in Fig. 3

\begin{tabular}{|c|c|c|c|c|}
\hline No. & Mass & Retention time & Formula & Presence \\
\hline A & $197 \cdot 1172$ & 1.673 & $\mathrm{C}_{9} \mathrm{H}_{15} \mathrm{~N}_{3} \mathrm{O}_{2}$ & WMP, EE \\
\hline B & 244.0849 & $2 \cdot 066$ & $\mathrm{C}_{13} \mathrm{H}_{12} \mathrm{~N}_{2} \mathrm{O}_{3}$ & WMP, WE, EE \\
\hline C & $156 \cdot 0427$ & $2 \cdot 246$ & $\mathrm{C}_{7} \mathrm{H}_{8} \mathrm{O}_{4}$ & WMP, WE \\
\hline D & 390.1539 & 5.863 & $\mathrm{C}_{18} \mathrm{H}_{22} \mathrm{~N}_{4} \mathrm{O}_{6}$ & WMP, WE \\
\hline E & $147 \cdot 0546$ & 1.561 & $\mathrm{C}_{5} \mathrm{H}_{9} \mathrm{NO}_{4}$ & WMP, EE \\
\hline $\mathrm{F}$ & $130 \cdot 0627$ & $2 \cdot 010$ & $\mathrm{C}_{6} \mathrm{H}_{10} \mathrm{O}_{3}$ & WMP, WE \\
\hline G & 448.0609 & 1.490 & $\mathrm{C}_{16} \mathrm{H}_{20} \mathrm{~N}_{2} \mathrm{O}_{9} \mathrm{~S}_{2}$ & WMP, WE, EE \\
\hline $\mathrm{H}$ & 464.0350 & 1.492 & $\mathrm{C}_{11} \mathrm{H}_{15} \mathrm{~N}_{4} \mathrm{O}_{10} \mathrm{~S}_{3}$ & WMP, EE \\
\hline I & $327 \cdot 1326$ & 1.850 & $\mathrm{C}_{16} \mathrm{H}_{17} \mathrm{~N}_{5} \mathrm{O}_{3}$ & WMP WE, EE \\
\hline $\mathrm{J}$ & $249 \cdot 1571$ & $1 \cdot 874$ & $\mathrm{C}_{11} \mathrm{H}_{23} \mathrm{NO}_{5}$ & WMP, WE \\
\hline $\mathrm{K}$ & $402 \cdot 1752$ & 4.509 & $\mathrm{C}_{12} \mathrm{H}_{22} \mathrm{~N}_{10} \mathrm{O}_{6}$ & WMP, EE \\
\hline L & 302.0915 & 2.065 & $\mathrm{C}_{16} \mathrm{H}_{10} \mathrm{~N}_{6} \mathrm{O}$ & WMP EE \\
\hline M & $187 \cdot 0841$ & $2 \cdot 260$ & $\mathrm{C}_{8} \mathrm{H}_{13} \mathrm{NO}_{4}$ & WMP, WE \\
\hline $\mathrm{N}$ & 432.0903 & 1.488 & $\mathrm{C}_{12} \mathrm{H}_{20} \mathrm{~N}_{2} \mathrm{O}_{15}$ & WMP, WE \\
\hline $\mathrm{O}$ & $327 \cdot 2770$ & $17 \cdot 217$ & $\mathrm{C}_{19} \mathrm{H}_{37} \mathrm{NO}_{3}$ & WMP, WE \\
\hline a & 364.0995 & 1.519 & $\mathrm{C}_{14} \mathrm{H}_{20} \mathrm{O}_{11}$ & WMP \\
\hline b & $188 \cdot 1530$ & 1.551 & $\mathrm{C}_{9} \mathrm{H}_{20} \mathrm{~N}_{2} \mathrm{O}_{2}$ & WMP \\
\hline c & $137 \cdot 0483$ & 1.571 & $\mathrm{C}_{7} \mathrm{H}_{7} \mathrm{NO}_{2}$ & WMP \\
\hline d & 293.1489 & 1.703 & $\mathrm{C}_{18} \mathrm{H}_{19} \mathrm{~N}_{3} \mathrm{O}$ & WMP \\
\hline $\mathrm{e}$ & $401 \cdot 6738$ & 4.510 & & WMP \\
\hline$f$ & $146 \cdot 0734$ & 1.553 & $\mathrm{C}_{10} \mathrm{H}_{10} \mathrm{O}$ & WMP \\
\hline g & $246 \cdot 1836$ & $15 \cdot 007$ & $\mathrm{C}_{13} \mathrm{H}_{26} \mathrm{O}_{4}$ & WMP \\
\hline $\mathrm{h}$ & $174 \cdot 1122$ & 1.472 & & WMP \\
\hline i & $360 \cdot 2898$ & 23.359 & $\mathrm{C}_{21} \mathrm{H}_{36} \mathrm{~N}_{4} \mathrm{O}$ & WMP \\
\hline j & $324 \cdot 1072$ & 1.555 & $\mathrm{C}_{12} \mathrm{H}_{20} \mathrm{O}_{10}$ & WMP \\
\hline $\mathrm{k}$ & $255 \cdot 0781$ & $1 \cdot 717$ & $\mathrm{C}_{8} \mathrm{H}_{17} \mathrm{NO}_{6} \mathrm{~S}$ & WMP \\
\hline I & 103.3530 & 1.514 & & WMP \\
\hline $\mathrm{m}$ & 114.0790 & 1.595 & $\mathrm{C}_{5} \mathrm{H}_{10} \mathrm{~N}_{2} \mathrm{O}$ & WMP \\
\hline $\mathrm{n}$ & $309 \cdot 1137$ & 1.553 & $\mathrm{C}_{22} \mathrm{H}_{15} \mathrm{NO}$ & WMP \\
\hline 0 & $162 \cdot 0945$ & 1.547 & $\mathrm{C}_{5} \mathrm{H}_{14} \mathrm{~N}_{4} \mathrm{~S}$ & WMP \\
\hline $\mathrm{p}$ & 256.0858 & 3.009 & $\mathrm{C}_{14} \mathrm{H}_{12} \mathrm{~N}_{2} \mathrm{O}_{3}$ & WMP \\
\hline$q$ & $315 \cdot 1205$ & 1.662 & & WMP \\
\hline $\mathrm{r}$ & 177.0996 & 1.807 & & WMP \\
\hline
\end{tabular}
soluble Mukitake extract.

the EE group, we consider that $\mathrm{EE}$ has a preventive function for visceral obesity and hepatic steatosis through the enhancement of the serum adiponectin level.

In addition, differential analysis between Mukitake and Shiitake, mycelia from the same family, using liquid chromatography time-of-flight MS technology revealed that there are seven and five compounds that only exist in WE and EE, respectively (Fig. 3 and Table 6). Further structural identification and evaluation of physiological properties of these compounds would be necessary in future study.

In conclusion, the present study demonstrated that Mukitake contains at least two different physiological substances that alleviate NAFLD: one through the reduction in MCP-1 production by its interference in the IKK $\beta-N F-\kappa B$ signalling pathway and the other through an increase in the serum adiponectin level and the prevention of visceral fat accumulation.

\section{Acknowledgements}

We thank Tomomi Yokota and Kazuyoshi Morinaga for their technical assistance. The authors declare no conflicts of interest. M. I. and K. N. made substantial contributions to the conception and design of the study, performing the experiment, assembly, analysis and interpretation of data and drafting the manuscript. S. N., B. S., N. I., N. N. and
H. N. participated in the experimental work and collection, assembly and analysis of data. T. T. and T. Y. contributed to planning of the experiment and in discussion of the results. The present study was supported by a research grant from the Japanese Ministry of Education, Culture, Sports, Science and Technology.

\section{References}

1. Kissebah AH \& Krakower GR (1994) Regional adiposity and morbidity. Physiol Rev 74, 761-811.

2. Formiguera X \& Canton A (2004) Obesity: epidemiology and clinical aspects. Best Pract Res Clin Gastroenterol 18, 1125-1146.

3. Hjelkrem MC, Torres DM \& Harrison SA (2008) Nonalcoholic fatty liver disease. Minerva Med 99, 583-593.

4. Harrison SA \& Diehl AM (2002) Fat and the liver - a molecular overview. Semin Gastrointest Dis 13, 3-16.

5. Youssef W \& McCullough AJ (2002) Diabetes mellitus, obesity, and hepatic steatosis. Semin Gastrointest Dis 13, 17-30.

6. Fong DG, Nehra V, Lindor KD, et al. (2000) Metabolic and nutritional considerations in nonalcoholic fatty liver. Hepatology 32, 3-10.

7. Reid AE (2001) Nonalcoholic steatohepatitis. Gastroenterology 121, 710-723.

8. Angulo P (2005) Nonalcoholic fatty liver disease. Rev Gastroenterol Mex 70, 52-56.

9. Clark JM, Brancati FL \& Diehl AM (2002) Nonalcoholic fatty liver disease. Gastroenterology 122, 1649-1657.

10. Angulo P (2007) GI epidemiology: nonalcoholic fatty liver disease. Aliment Pharmacol Ther 25, 883-889.

11. Day CP (2002) Pathogenesis of steatohepatitis. Best Pract Res Clin Gastroenterol 16, 663-678.

12. Gary-Bobo M, Elachouri G, Gallas JF, et al. (2007) Rimonabant reduces obesity-associated hepatic steatosis and features of metabolic syndrome in obese Zucker $\mathrm{fa} / \mathrm{fa}$ rats. Hepatology 46, 122-129.

13. Nagao K, Inoue N, Wang YM, et al. (2005) Dietary conjugated linoleic acid alleviates nonalcoholic fatty liver disease in Zucker $(\mathrm{fa} / \mathrm{fa})$ rats. J Nutr 135, 9-13.

14. Shirouchi B, Nagao K, Inoue $\mathrm{N}$, et al. (2008) Dietary phosphatidylinositol prevents the development of nonalcoholic fatty liver disease in Zucker $(\mathrm{fa} / \mathrm{fa}$ ) rats. J Agric Food Chem 56, 2375-2379.

15. Nagao K \& Yanagita T (2008) Bioactive lipids in metabolic syndrome. Prog Lipid Res 47, 127-146.

16. Chang R (1996) Functional properties of edible mushrooms. Nutr Rev 54, S91-S93.

17. Wasser SP (2002) Medical mushrooms as a source of antitumor and immunomodulating polysaccharides. Appl Microbiol Biotechnol 60, 258-274.

18. Ukawa Y, Furuichi Y, Kokean Y, et al. (2002) Effect of hatakeshimeji (Lyophyllum decastes Sing.) mushroom on serum lipid levels in rats. J Nutr Sci Vitaminol 8, 73-76.

19. Zaidman BZ, Yassin M, Mahajna J, et al. (2005) Medical mushroom modulators of molecular targets as cancer therapeutics. Appl Microbiol Biotechnol 67, 453-468.

20. Watanabe A, Kobayashi M, Hayashi S, et al. (2006) Protection against D-galactosamine-induced acute liver injury by oral administration of extracts from Lentinus edodes mycelia. Biol Pharm Bull 29, 1651-1654.

21. Ukawa Y, Izumi Y, Ohbuchi T, et al. (2007) Oral administration of the extract from Hatakeshimeji (Lyophyllum decastes Sing.) mushroom inhibits the development of 
atopic dermatitis-like skin lesions in NC/Nga mice. J Nutr Sci Vitaminol 53, 293-296.

22. Nagamori N (2007) Simple equipment cultivation of Panellus serotinus. Kyushu J Forrest Res 60, 146-148.

23. Nagao K, Inoue N, Inafuku M, et al. (2010) Mukitake mushroom (Panellus serotinus) alleviates nonalcoholic fatty liver disease through the suppression of monocyte chemoattractant protein 1 production in $d b / d b$ mice. $J$ Nutr Biochem 21, 418-423.

24. Folch J, Lees M \& Sloane Stanley GH (1957) A simple method for the isolation and purification of total lipides from animal tissues. J Biol Chem 226, 497-509.

25. Fletcher MJ (1968) A colorimetric method for estimating serum triglycerides. Clin Chim Acta 22, 393-397.

26. Sperry WM \& Webb M (1950) A revision of the Schoenheimer-Sperry method for cholesterol determination. $J$ Biol Chem 187, 97-106.

27. Ochoa S (1955) Malic enzyme: malic enzymes from pigeon and wheat germ. Methods Enzymol 1, 323-326.

28. Kelley DS \& Kletzien RF (1984) Ethanol modulation of the hormonal and nutritional regulation of glucose 6-phosphate dehydrogenase activity in primary cultures of rat hepatocytes. Biochem J 217, 543-549.

29. Kelley DS, Nelson GJ \& Hunt JE (1986) Effect of prior nutritional status on the activity of lipogenic enzymes in primary monolayer cultures of rat hepatocytes. Biochem $J \mathbf{2 3 5}$, 87-90.

30. Hummel KP, Dickie MM \& Coleman DL (1966) Diabetes, a new mutation in the mouse. Science 153, 1127-1128.

31. Chen H, Charlat O, Tartaglia LA, et al. (1996) Evidence that the diabetes gene encodes the leptin receptor: identification of a mutation in the leptin receptor gene in $d b / d b$ mice. Cell 84, 491-495.

32. Lee GH, Proenca R, Montez JM, et al. (1996) Abnormal splicing of the leptin receptor in diabetic mice. Nature 379 , 632-635.

33. Marceau P, Biron S, Hould FS, et al. (1999) Liver pathology and the metabolic syndrome $\mathrm{X}$ in severe obesity. J Clin Endocrinol Metab 84, 1513-1517.

34. Marchesini G, Brizi M, Bianchi G, et al. (2001) Nonalcoholic fatty liver disease: a feature of the metabolic syndrome. Diabetes 50, 1844-1850.
35. Marchesini G, Bugianesi E, Forlani G, et al. (2003) Nonalcoholic fatty liver, steatohepatitis, and the metabolic syndrome. Hepatology 37, 917-923.

36. Hotamisligil GS (1999) The role of TNF $\alpha$ and TNF receptors in obesity and insulin resistance. J Intern Med 245, 621-625.

37. Cave M, Deaciuc I, Mendez C, et al. (2007) Nonalcoholic fatty liver disease: predisposing factors and the role of nutrition. J Nutr Biochem 18, 184-195.

38. Baggiolini M (1998) Chemokines and leukocyte traffic. Nature 392, 565-568.

39. Sartipy P \& Loskutoff DJ (2003) Monocyte chemoattractant protein 1 in obesity and insulin resistance. Proc Natl Acad Sci USA 100, 7265-7270.

40. Kanda H, Tateya S, Tamori Y, et al. (2006) MCP-1 contributes to macrophage infiltration into adipose tissue, insulin resistance, and hepatic steatosis in obesity. J Clin Invest 116, $1494-1505$

41. Maeda N, Shimomura I, Kishida K, et al. (2002) Diet-induced insulin resistance in mice lacking adiponectin/ACRP30. Nat Med 8, 731-737.

42. Karin M \& Delhase M (2000) The IкB kinase (IKK) and NF-кB: key elements of proinflammatory signalling. Semin Immunol 12, 85-98.

43. Ghosh S \& Karin M (2002) Missing pieces in the NF-кB puzzle. Cell 109, S81-S96.

44. Kim JK, Kim YJ, Fillmore JJ, et al. (2001) Prevention of fat-induced insulin resistance by salicylate. J Clin Invest 108, 437-446.

45. Grundy SM (2004) Obesity, metabolic syndrome, and cardiovascular disease. J Clin Endocrinol Metab 89, 2595-2600.

46. Matsuzawa Y (2005) Adipocectin: identification, physiology and clinical relevance in metabolic and vascular disease. Nat Clin Pract Cardiovasc Med 6, 7-14.

47. Xu A, Wang Y, Keshaw H, et al. (2003) The fat-derived hormone adiponectin alleviates alcoholic and nonalcoholic fatty liver disease in mice. J Clin Invest 112, 91-100.

48. Lopez-Bermejo A, Botas P, Funahashi T, et al. (2004) Adiponectin, hepatocellular dysfunction and insulin sensitivity. Clin Endocrinol 60, 256-253.

49. Bajaj M, Suraamornkul S, Piper P, et al. (2004) Decreased plasma adiponectin concentrations are closely related to hepatic fat content and hepatic insulin resistance in pioglitazone-treated type2 diabetes patients. J Clin Endocrinol Metab 89, 200-206. 